\title{
Making the difference with active parenting; forming educational partnerships between parents and schools
}

\author{
Ron Oostdam • Edith Hooge
}

Received: 30 November 2011 /Revised: 31 January 2012 / Accepted: 22 February 2012 /

Published online: 14 March 2012

(C) The Author(s) 2012. This article is published with open access at Springerlink.com

\begin{abstract}
Although parental involvement is often a priority on the quality agenda of schools for primary and secondary education, it is still not usual to involve parents as an educational partner in the actual learning process of their child. Rather than adopting an open approach, teachers tend to tell parents what they should do or keep them at a safe distance. At the same time, parents are increasingly becoming better informed, more critical and thus are more strongly positioned towards school. They address teachers more directly in case of problems or disappointing results of their child. Clearly, this might lead to a negative impact on the mutual relationship especially when parents' emotional involvement conflicts with a professional and detached attitude of teachers. Based on the results of several studies that provide ample evidence that parental involvement in the learning process can improve learning outcomes, it is argued that there is much to be gained in forming educational partnerships between parents and schools. Different dimensions of active parenting are discussed, as well as prerequisites for successful implementation.
\end{abstract}

Keywords Parental involvement · Educational partnership · Pedagogical partnership · Didactical partnership $\cdot$ Learning process $\cdot$ Learning outcomes

\section{Introduction}

Schools usually make quality improvements on various levels in order to enhance their pupils' performance. This can involve, for example, further professionalization of teaching staff, the implementation of new teaching methods or the optimisation of facilities in the

\footnotetext{
R. Oostdam $(\bowtie)$

University of Amsterdam, P.O. Box 94208, 1090 GE Amsterdam, the Netherlands

e-mail: r.j.oostdam@uva.nl

E. Hooge

Amsterdam University of Applied Sciences, Wibautstraat 2-4, 1091 GM Amsterdam, the Netherlands e-mail: e.h.hooge@hva.nl
} 
field of electronic resources. Improving the level of parental involvement is often a priority on the quality agenda of schools as well. This certainly involves more than simply approaching parents to join the parent-teachers association, help to organise a school camp or maintain the school garden. Increasingly, the focus is on actively involving parents in their child's educational learning process at school (cf. Crozier 2005; Evangelou et al. 2008). Schools experience that there is much to be gained from this and that direct involvement of parents does make a difference (cf. Oostdam and Van Loo 2011).

It is known from research that involving parents can have a positive effect on motivation and well-being at school as well as the child's learning outcomes (e.g. Epstein 2001; Fan and Chen 2001; Desforges and Abouchaar 2003; Jeynes 2003; Mcwayne et al. 2004; Fantuzzo et al. 2004; Sylva et al. 2004; Gonzalez-Dehass et al. 2005; Hoover-Dempsey et al. 2005; Harris and Chrispeels 2006; Smit et al. 2006; Harris and Goodall 2007; Smit et al. 2007; Patall et al. 2008). The most determinative factor in parental involvement appears to be what could be called good parenthood in the home situation (cf. Desforges and Abouchaar 2003; Fantuzzo et al. 2004; McWayne et al. 2004). This factor is characterised by the establishing of a safe and stable home setting, stimulation of intellectual development, e.g. by discussions between parent and child, modelling, disseminating the importance of education and fostering high expectations about children's school success. By engaging in educational activities with their children at home (homework, reading, modelling), parents communicate their expectations for achievement (cf. Hoover-Dempsey et al. 2001, 2002). All this brings the school curriculum goals within the situation at home. For instance, the linguistic development of primary school pupils depends strongly on the language environment at home (cf. Leseman and De Jong 1998; Dearing et al. 2004, 2006; Lynch 2009; Merlo et al. 2007). This relates not only to differences in the parents' level of education but also to the number of different words and the complexity of sentences the children hear (cf. Hoff 2006). It is also well-known that reading to children at home makes an important contribution to their linguistic development (cf. Leseman et al. 2007). At the same time, also negative effects of parental involvement for a subject matter as mathematics are reported (cf. Patall et al. 2008). Most probably this can be explained as a result of a discrepancy between the given explicit instruction at school and the instruction parents provide at home (cf. Cooper et al. 2000). Therefore, as the occasion arises, it might be necessary to teach parents in using specific instructional techniques (cf. Hoover-Dempsey et al. 2002).

The review study by Menheere and Hooge (2010) also shows an inverse relationship between parental involvement and performance at school. Disappointing results at school are often a direct reason for parents to address the teacher. If all is going well at school, most parents do not often seek contact. They do not do so unless the child is not doing well or if problems arise (Todd and Higgins 1998). In this respect, there are differences between the parents of high-achieving children and the parents of children who are performing poorly. Parents of high-achieving children are often closely involved in school life, from the 'strategic' consideration of stimulating their child's learning achievements. These parents are quick in seeking contact and asking the school to act. In the majority of cases, the parents of children who are performing poorly tend to adopt a 'wait and see' attitude in respect of the school, although they do think it is important that their child does well (cf. Morrison Gutman and McLoyd 2000; Smit et al. 2006).

Schools and teachers are considered to be in a key position when it comes to furthering parental involvement and ensuring an effective exchange of information about life at school and home (cf. Oostdam 2009). Although schools find it important that parents become more involved and are of the opinion that this should be improved, they are not always sure how to 
go about this (cf. Dom 2006). In addition, research among parents shows that they generally have a positive opinion about their relationship with the school but think that there is considerable room for improvement (cf. Peetsma and Blok 2007). For example, when schools involve parents in drawing up an educational treatment plan for their child and obtaining information about the evaluation of the plan, there often is a discrepancy between the parents' and teachers' input. Parents are generally well informed about their child's abilities and limitations, while teachers are experts when it comes to deciding on teaching material and the best way to teach. This often leads to problems in discussions between parents and teachers, which is probably an important reason for teachers to adopt a restrained, cautious approach towards parents (cf. Harris and Goodall 2008). Rather than adopting an open approach, teachers tend to tell parents what they should do, or-if the parents prove to be too strong an opposite number-keep them at a distance (cf. Lareau 1997; Crozier 2000; Van Loo 2004; Addi-Raccah and Ariv-Elyashiv 2008; Oostdam and Van Loo 2011).

In this article, a terminological framework is presented for different levels of parental involvement in schools. Based on this framework, an elaboration is given of the concept of active parenting. Different dimensions of parental involvement are discriminated and defined as partnerships between parents and school. The different types of partnership are illustrated with examples from educational contexts observed at several schools for primary and secondary education in the Netherlands using the framework of active parenting for developing innovative practices on parental involvement. Explicit focus is given to establishing an educational partnership and prerequisites for successful implementation are discussed. Finally, a typology is given for assessing schools in relation to active parenting and educational partnership.

\section{Different levels of partnership}

A general term such as 'parental involvement' can refer to many things (cf. Epstein 2001; De Vries 2007; Oostdam and Van Loo 2011; Menheere and Hooge 2010). People often use it without having a clear idea of its precise meaning, which clouds the discussion at both school and parent level. For example, a school may emphasise its commitment to broad parental involvement, while in practice this is mainly limited to active input from parents in organising school activities. It is therefore important to define precisely what we mean when talking about parental involvement. Only with a clear terminological framework schools' expectations and requirements of parents can be explicitly indicated. It also provides a basis for defining what form of involvement the school (and teachers) are seeking, or definitely not seeking.

Parents can be involved in school life in various ways and on several levels (e.g. Bastiani 1987; Epstein 2001; Patall et al. 2008). In general, the literature makes a distinction between parental involvement and parental participation (cf. Smit et al. 2007). Parental involvement is usually defined as a more active form of involvement of parents in the bringing up and education of their child, while parental participation is taken to indicate active participation by parents in a range of school activities. With regard to parental participation, a further distinction is made between institutional activities, such as membership of the parents' council or parent-teachers association, and non-institutional activities, such as helping to clean the school or helping in the school media library (cf. Epstein 2001; Karsten et al. 2006). In the typology of Epstein (2001), institutional activities are indicated as 'decision making and advocacy' and non-institutional activities as 'volunteering'. Although parental 
involvement appears to have a more positive effect on children's development than parental participation (Desforges and Abouchaar 2003), both forms are closely related. Parents which show active forms of parental involvement are usually also more active in the field of parental participation (McWayne et al. 2004) and tend to be more involved in activities in the community (Morrison Gutman and McLoyd 2000).

Here the umbrella term active parenting is used to denote various forms of parental involvement (cf. Kranenburg 2009; Oostdam and Van Loo 2011). To a greater extent than current concepts such as parental involvement or participation, the term 'active parenting' has the connotation of parents who consciously and proactively commit themselves to various activities in mutual consultation with the school. In addition, the concept of 'active parenting' has not (yet) acquired a specific meaning in educational practice and is therefore suitable for use as an umbrella term.

Within the context of a large research project in the Netherlands focussed on improving active parenting at schools, different practical applications were developed for more powerful and effective partnerships for parental involvement. The main aim was to trial new practical approaches for engaging parents in school and more particularly in the learning process of their child. The examples inserted to illustrate the different dimensions of parental involvement are all derived from participating schools.

Based on a review of the literature, discussions with teachers and results of the trials at schools, a framework for active parenting was developed in which three types of partnerships between parents and school were discerned. The term 'partnership' has been chosen because, in recent years, there has been an increasing shift in the roles of parents and schools (Dutch Advisory Council for Education 2003). Originally, the roles were clearly delineated: Parents are responsible for bringing up the children, and the school is responsible for education (cf. Fan and Chen 2001). Gradually, this distinction has become blurred, and upbringing and education are seen more as a shared responsibility of parents and schools (Menheere and Hooge 2010). In that context, the term 'partnership' is used to describe meaningful school-parent cooperation in which the two parties consult and support each other in furthering the learning, motivation and development of pupils (De Wit 2005).

A social partnership involves cooperation between parents and school with regard to all manner of local out-of-school activities. Epstein (2001) designates this type of partnership as 'collaborating with the community'. For example, the school provides easier access to children and their parents to a range of social amenities by arrangements with a sports or music school to offer certain courses. The school can act as an intermediary, in particular, if the children cannot make use of these facilities because of financial constraints at home. Social partnership can also relate to diverse facilities or activities offered at the school outside school hours. In such cases, we speak of 'extended schools' (cf. Hooge 2008).

A formal partnership relates to the involvement of parents in all manner of school activities. Without such voluntary assistance of parents, the organisation of many schools would 'collapse'. This relates to activities such as accompanying children and helping to organise excursions, creative and cultural activities, organising school lunch programmes, managing a documentation centre etc. Formal partnership, as it is defined here, largely corresponds to the concept of parental participation mentioned above.

Within the context of this article, we particularly focus on educational partnership - the middle part of Fig. 1-because active parenting within this dimension is explicitly directed on guiding and improving the learning process of children. It involves parents and the school dealing with pedagogical and didactical issues together (see the example 'Pedagogical 


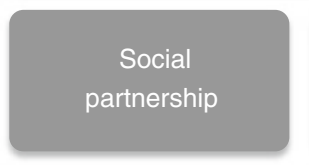

Together in the community

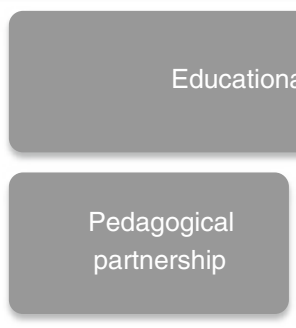

Educational partnership

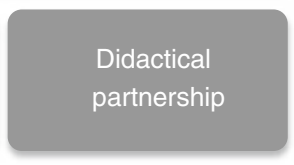

Formal

partnerschip

Voluntary work Parents' council, Board,

Parent-teachers association

Fig. 1 Dimensions of active parenting

Climate'). The term 'educational partnership' is in fact synonymous with the concept of parental involvement given before. For a more precise definition, however, a distinction is made between a pedagogical and didactical partnership.

\footnotetext{
Pedagogical Climate

In the sixth grade of a primary school, the children give each other feedback on various activities. During the project weeks, pupils make suggestions to each other about how to improve their project. Parents and children have observed that, during these feedback opportunities, some children feel very hurt by the 'criticism' they receive. As a consequence of these repeated observations, teachers and parents formed a working group on the pedagogical climate in the school. After a serious conflict between a number of parents about the 'criticising' of children at school, the school leader and parents' council took the initiative to open up a school-wide discussion on the theme of the pedagogical climate. In the working group, the parents and teachers discussed the strengths and weaknesses of the pedagogical climate. Was the 'harsh' treatment of some pupils when giving feedback during the project weeks incidental, or an indication of an unsafe pedagogical climate? The parents wondered what the children themselves thought about this. In order to find out, a survey was carried out among the pupils. This produced a clear picture of situations in which children did not feel safe. During a parents' evening, all parents had the opportunity to discuss a safe pedagogical climate. Several situations emerged that parents, pupils and teachers would like to see improved. These related not only to children giving feedback to each other, but also to bullying in the playground and after school. The idea arose to set up a pupils' council, so that the children can also help to find effective solutions.
}

In a pedagogical partnership, the emphasis is on cooperation between parents and the school in order to avoid a situation in which school and home are two separate worlds. Research shows that teachers, but particularly parents, are much less satisfied with the relationship between school and family when it comes to contacts about parenting (cf. Hoover-Dempsey and Sandler 1995, 1997; Crozier and Davies 2007; Peetsma and Blok 2007; Harris and Goodall 2008). Parents like to join discussions on parenting issues such as punishment and reward, the teaching of norms and values, dealing with bullying, safety and providing guidance for children (cf. Van Loo 2004; Menheere and Hooge 2010), but teachers sometimes show a resistance to parents interfering (Todd and Higgins 1998; De Carvalho 2001; Addi-Raccah and Ariv-Elyashiv 2008). However, parents' responsibility for their child's upbringing does not stop at the school gates, and to a certain extent, the school shares that responsibility. Out of respect for the child's world, the school can respond to experiences and skills that the children bring from outside the school environment. Through cooperation with parents, the school receives feedback about its own work, which will ultimately benefit the quality of its pedagogical practices and the pedagogical climate. Teachers feel encouraged if they know that parents support them and are involved in what 
goes on at school. Moreover, this cooperation can help to raise parents' awareness with regard to parenting at home (cf. Hoover-Dempsey and Sandler 1995; Smit et al. 2006).

A didactical partnership is geared towards enhancing the effectiveness of education by keeping parents well informed about, and involving them in, their child's learning process (see the example 'Research Activities'). Parent reading assistants, for example, carry out educational support tasks and can contribute to educational objectives such as adaptive reading instruction. Through good cooperation with the school, parents can also contribute to their child's learning development by providing specific support at home to help children acquire 'school-related' skills.

\footnotetext{
Research Activities

Pupils in the first year of secondary education spend three weeks a year working on a research task of their own. It is not only the piece of work or report on the research, but also the process of working on the task that provides valuable information on the extent to which the child has acquired various skills. The research task is therefore used in order to observe how the child tackles the work and, on the basis of what is observed, to offer the child assistance in taking the next step. Each child chooses a subject that he/she would like to know more about, such as: Where do 'hundreds and thousands' come from? Why do some trees stay green in the winter? What does an architect do?

At home and at school, the children researched their chosen subject. Parents helped them, but were not always sure precisely what was expected of them in terms of guidance. The school therefore organised an information evening for parents and pupils. The subjects discussed at this evening were partly content-related, namely:

- How do you gather information?

- How do you organise the information you have found?

- How do you make a report of your research?

Parents were also advised on how to give feedback to their child(ren): what type of feedback helps a child to work on the research task? Thanks to the information evening, parents had a clear idea of the purpose of the task, the criteria on which the report or piece of work would be evaluated, how to give feedback to the pupil, the forms of assistance given at school, and how best to assist without taking over too much of their child's work.
}

The precise nature of the various levels of active parenting is also subject to the changes in the social context of schools. Over the last decade, schools have increasingly been pressured to address a wide range of social issues such as integration, coping with social media, safety, citizenship, obesity, financial debts and so on (Hooge et al. 2011). Moreover, as a result of increasing individualisation, the general rise in the level of parents' education, the increase in (access to) information provided by the government or the Internet, parents have become better informed, more critical and thus are more strongly positioned towards school.

\section{Mutual expectations}

Although good cooperation between parents and school in terms of an educational partnership may imply that they have an equal status in the partnership, it does not mean that they are equal to each other (Epstein 2001). In fact, parents and school have differing intentions, interests, stakes and responsibilities (cf. Lareau 1997; Todd and Higgins 1998; Dom 2006). This is particularly evident when we consider the personal - and therefore-emotional involvement of parents with their child whereas teachers are rather professionally than personally involved. The relationship between parent and child is characterised by vertical loyalty (cf. Hargrave et al. 2007). Vertical loyalty is loyalty to those who have given us the most fundamental of all things: life itself. Parents do not like to hear anything bad said about their children. And when children decide, after a long period of vacillation, to talk about 
their parents' faults, this does not mean that others may do so too. Therefore, it is important that the school is aware of the difference between vertical loyalty to parents and horizontal loyalty to, for example, friends, neighbours or teachers. Horizontal loyalty is shown in mutual relationships that have been entered into by choice and can be ended. Someone who receives too little from a friendship can always choose to end his/her association with the person concerned. The relationship between parent and child is not so 'discretionary', however.

Thus, equal status in the partnership should not conceal the fact that parents and school can have differing expectations regarding their respective responsibilities, and their opinions can differ considerably as to what constitutes 'optimum' conditions for children's development and learning (cf. Smit et al. 2006). This becomes particularly evident when the parents' emotional involvement comes up against a professional and detached attitude on the part of the school. Mutual trust is therefore essential in building and maintaining a parent-school partnership. When parents and the school succeed in combining information about the child's strengths and weaknesses, about their vision and expectations regarding the child's capacity for growth and the steps to be taken in its development possibilities, this benefits mutual trust as well as the child's development. The professionalism of teachers and the openness and flexibility of the school are key factors to this (cf. Adams and Christenson 2000; Morrison Gutman and McLoyd 2000; Anderson-Butcher 2004).

\section{Basic needs of teachers, pupils and parents}

Stevens (1997) formulates three basic psychological needs of pupils that must be met if they are to remain motivated during the learning process: the need for relationships ('you belong'), the need for competencies ('you have abilities') and the need for autonomy ('you can make a decision about something'). A good parent-school partnership is one that takes account of these basic needs (see Fig. 2).

First there is the need for relationships between team members, parents and children featured by a sense of 'belonging' and safety. In such relationships, trust flourishes and is it possible to take initiatives and develop.

The second need is that team members, parents and children are seeing themselves as competent, having a grip on the world around them and controlling matters and events in which they are directly involved. As they become more successful in this, their confidence grows and they begin to have high expectations of themselves. Showing mutual appreciation

Fig. 2 Basic psychological needs

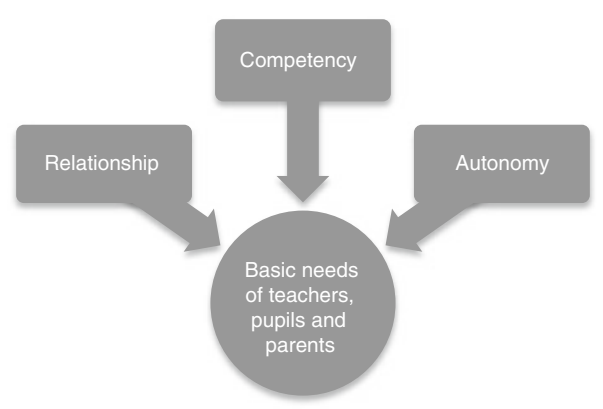


and acknowledgement reinforces this. However, according to a number of studies, parents are quite unsure about their role and possibilities in their child's learning (cf. Menheere and Hooge 2010). It turns out that the extent to which the school encourages and supports active involvement has a strong influence on their ultimate decision to actually do something (cf. Harris and Goodall 2007). Good, clear information for parents about what is expected and asked of them for certain homework tasks is often greatly appreciated and stimulates an active effort and self-confidence.

The third need concerns autonomy: decision making and acting on own initiative. In order to enable teachers and parents to act from a position of autonomy, their various duties and responsibilities are to be clearly delineated, which calls for a clear explicit school vision on this. The previous example of educational partnership (pedagogical climate) illustrates parent-teacher cooperation in the form of a working group in which the two parties, from their respective positions of autonomy, each has a clear role.

As indicated above, a partnership between parents and school does not mean that they are equal to each other. Both parties have their own responsibilities. If the school wishes to communicate its commitment to active parenting, this is a conscious choice. The school will in fact have to take the initiative in this, based on a vision of what is good for children's development and learning. This means that school itself largely determines the playing field and 'rules' related to partnership with parents. Taking account of mutual expectations and the underlying basic needs of the parties involved, the school must determine what it requires and wishes of parents. This involves answering questions such as: What do we do if parents do not wish to take on the role of equal partner? Is it acceptable if parents do not wish to commit themselves, and seldom or never make an appearance? Which (minimum) requirements are there with regard to parental involvement?

\section{Communicating with parents}

A school that wishes to further pursue active parenting is immediately confronted with the stubborn reality that there are many different types of parents. The differences can relate to the level of education, social-cultural background, learnedness, income and all manner of background variables (cf. Reay 1998; Crozier and Davies 2007; Harris and Goodall 2007; Sacker et al. 2002).

Parents with a higher level of education often attach greater importance to their children's autonomy and independence. Parents with a low level of education think it important for their children to be obedient, have respect for their elders and comply with current rules and views (cf. Smit et al. 2006). Some immigrant parents place less emphasis on selfresponsibility and self-determination and more emphasis on social responsibility-i.e. on collective rather than individualistic aspects of social sensibility. With regard to ambition, there is a considerable difference between immigrant and non-immigrant parents with a low level of education. Notably, immigrant parents find it very important that their children do well (Smit et al. 2007). This presumably stems from the fact that the opportunities for upward mobility prompted the migration of these parents. Non-immigrant parents with a low level of education usually have few expectations of education. In many cases, they did not complete their own education in school (cf. Flemish Advisory Council for Education 2001).

Parents can also differ widely in the extent to which they are involved with the school. Some parents are 'invisible' to the school and 'hard to reach' (cf. Harris et al. 2007; Harris and Goodall 2008). They 'drop their child off' and leave straightaway. Other parents are regularly present and are always available to go along on a school trip or camp. After a 
period of time, every school, consciously or otherwise, can categorise parents by their (visible) involvement. It is important to obtain a clear picture of the different types of parent, so that the school can take the differences into account when building an educational partnership. The school must also take account of the fact that parents have different roles. A parent with administrative experience who is active on the school board can react just as emotionally or angrily as any other parent towards a teacher if its child is not doing well at school.

Apart from pupils, parents are the most important target group for schools to communicate with. However, in general, teachers and schools appear not very well prepared for this (Menheere and Hooge 2010). In the initial and post-initial teacher training programmes, teachers are not made enough aware of the many aspects of parent-school relationships besides informing parents about children's learning and progress. They could be taught knowledge and skills in order to make parents feel that they are welcome in the school and that they are respected by the school staff as partners in education.

In the interest of good communication, it is important that the school formulates a clear policy vision with regard to the relationship with parents. Central to this is the question of whether parents are seen as clients, or more as partners in the context of an educational partnership. It must also be clear how parents can approach the school for information. Can they call in at the school at any time? Can they telephone the school (if so, who can they call and when?)? Can they contact the school via e-mail or a (interactive) website?

Each member of the school team is ultimately a representative of the school and shares the responsibility for putting into practice the school policy on communicating with parents. For each team member, a number of general basic skills are important for good relations with parents (see Van Loo 2004). This implies that team members are familiar with the school's vision and help to communicate it, act out of respect for parents and children, can be accessible and hospitable to parents within the school's rules and arrangements, are able to observe without judging, act with awareness and integrity (also with respect for relations with colleagues) and are able to indicate the boundaries of their own abilities and responsibilities.

\footnotetext{
Report discussion

A primary school follows the concept of experience-oriented education and wants to involve pupils more closely in discussions about their report with parents. In the first instance, this was introduced for pupils in the upper years (grades 4, 5 and 6). The first discussions were still very similar to the traditional 10-minute discussions in which the teachers explain the report and the parents ask questions and give their reaction. Now the pupil is also present, and gives his/her reaction to the report. The teachers were not very satisfied with this method. Gradually, it has evolved into a form of discussion in which the pupils themselves tell their parents about their report. The portfolio plays an important role in this. Pupils can show how they have developed and what results they have achieved. Pupils are prepared thoroughly by means of discussions about their portfolio with their teacher and fellow pupils. The experience of teachers and parents is that the discussions are more in depth, but also take up more time. It has now been decided to hold the report discussions with parents, pupil and teacher twice a year instead of three times a year.
}

A teacher must have a good understanding of the shared pedagogical and didactical responsibilities with respect to the parents. In order to communicate effectively with parents about their child's progress and well-being, a teacher must be able to respond appropriately to comments and questions (compare the example 'Report Discussion'). This means, for example, that the teacher talks to the parents about their child's progress and level of wellbeing at school and provides report on this at certain times. Furthermore, a teacher integrates child's signals and stories with information provided by parents; is aware of the significance of his/her role in respect of parents (in particular in situations where the school and home environments are very different); is able to take account of the interests, position and 
responsibilities of parents and communicates with parents about education-related work in an engaged, effective and interactive way. Important communicative skills in this context are active listening, summarising, showing appreciation, giving feedback and telling about things (the child, the school).

\section{Differences between schools in educational partnership}

In the context of active parenting, schools can cooperate with parents on various levels. Hence, the school is a junction of relationships. Interpersonal relations play an important role in parent-school communication, and as explained above, good communication is essential. One can say that a healthy school is a purposeful school. It has a clear vision for the future and an immediate mission for tomorrow. There are things to be done, and there is consensus as to what those things are. In their vision for interacting and communicating with parents, schools will seek an appropriate balance between professional distance and proximity, i.e. distance where boundaries protect the necessary autonomy of teacher and parent, and proximity where the relationship between parents and school grows through acknowledgement, appreciation and empathy.

It is important for a school team to determine what type of school it wants and is able to be for parents. Making a specific choice also makes it clear how the school wishes to work with the various forms of partnership illustrated in Fig. 1. In general, based on De Vries (2007), five types of school can be distinguished (see Fig. 3). The description is cumulative, in other words: school type 2 builds on school type 1, school type 3 includes all the characteristics of types 1 and 2 and school type 5 includes all the characteristics of types 1 to 4 .

In terms of educational partnership, the five types of school can be placed on a continuum. Information-oriented and structure-oriented schools do not enter into any form of educational partnership and do not focus on this. These schools may well regard parents as a social and formal partner, but not in the first place as an educational partner. Participationoriented and innovation-oriented schools are fully geared towards educational partnership.

1) Information-oriented school: focuses on providing accurate information to parents. Contacts with parents are formal with regard to providing information.

2) Structure-oriented school: in addition to providing accurate information, also focuses on establishing clear structures. The tasks and responsibilities of parents and school are clearly set out. Contacts with parents are formal and in accordance with fixed procedures.

3) Relation-oriented school: focuses on accurate information and clear structures, but also specifically on the relationship with parents. Attention is given to entering into and maintaining good (individual) contact with parents.

4) Participation-oriented school: focuses on providing accurate information, clear structures and a good relationship with parents, but also invests in optimum parent participation. The school is proactive in contacts with parents on all levels, and aims to establish active parenting in all aspects.

5) Innovation-oriented school: school establishes full active parenting, i.e. both school and parents are proactive. School and parents together focus on the continual improvement of education, school and school environment.

Fig. 3 Types of school in relation to educational partnership 
The innovation-oriented schools represent an ideal type. Relationship-oriented schools occupy a position in the middle.

Awarding stars can show the differences between the five types of school with regard to educational partnership. The innovation-oriented school would receive five stars for forming an educational partnership, while the information-oriented school would receive only one star. Obviously, it should be noted here that a school might have made a conscious decision to be of a particular type. A great deal can and will depend on the school's parent population. Furthermore, the type of educational partnership that a school creates is in no way an indicator of the quality of the education it provides. Although an information-oriented school has a low score in terms of educational partnership, based on a conscious decision, it may provide excellent education.

\section{Conclusion}

There is strong evidence that parental involvement can have a positive effect on children's learning motivation, well-being and learning outcomes at school. It is argued that teachers have a key position in facilitating such a parental involvement and that school itself largely determine the playing field and rules. At the same time, it is clear that most schools find it important to establish parental involvement, but are still not sure about how to deal with this. Rather than adopting an open approach, teachers tend to tell parents what they should do or keep them at a safe distance.

Parental involvement can refer to many different things and this may disturb the communication between parents and school as well as their mutual expectations. Therefore, a terminological framework is presented here for defining parental involvement more precisely within the context of schools. In doing so, the notion of active parenting is introduced to indicate parents who consciously and proactively commit themselves to various activities in mutual consultation with the school. By defining different dimensions of parental involvement, it is obvious that schools can differ widely in emphasising their commitment to parents. The concept of partnership is used to express that education at school and raising children at home are no longer to be separated strictly. In the last decade, there has been a shift towards a joint responsibility of schools and parents in children's education.

Within the framework of active parenting, three different types of partnership are distinguished. A social partnership is directed at cooperation between parents and school with regard to several out-of-school activities. A formal partnership is related to the involvement of parents in all kinds of institutional (e.g. parents' council) and noninstitutional activities (e.g. accompanying children and organising excursions). Finally, an educational partnership is discerned focussed on guiding, facilitating and improving the learning process of children. This educational partnership is defined more precisely in two different types, a didactical and a pedagogical partnership.

Within the educational practice, the three types of partnership cannot always be considered as completely independent. For example, taking part in the parents' council or the parent-teachers association falls under the heading of formal partnership. At the same time, there will be a direct relationship to educational partnership in case parents contribute ideas and advice on the content and quality of education in the parent-teachers association. It should also be emphasised that certain activities classified as part of a social or formal partnership can facilitate children's learning. Organising all kinds of out-of-school activities or offering diverse facilities outside school hours will not only contribute to more active parenting but also to a better learning environment for children. 
Focussing here on educational partnership there is ample evidence that parental involvement in the learning process can have a positive effect on children's learning outcomes, especially within the field of language. Although many factors have to be taken into account when schools and parents form an educational partnership, it is evident that mutual trust and equality is essential. Because both parties act on the basis of their own responsibilities and interests, it must be clear that they have a shared interest in the child's development and learning. In terms of trust between parents and school, the quality of the communication seems to be a better predictor than the frequency of communication (cf. Fantuzzo et al. 2004; Hoover-Dempsey et al. 2005).

As stated, parents differ as much as children. They do not only differ in terms of mentality, beliefs and behaviour but also in terms of background variables such as level of education, socioeconomic status and ethnic-cultural background. It is clear that the quality of parental involvement is determined by several factors. Obviously, schools need to cope with these differences between parents in forming educational partnerships.

Although a partnership between parents and school is one of equality, both have their own responsibilities. Therefore, it is important that schools obtain a clear picture of the different types of parents and formulate an unequivocal policy vision with regard to active parenting. In forming educational partnerships schools need to seek a balance between their professional distance and autonomy versus a positive and open attitude towards parental involvement.

Open Access This article is distributed under the terms of the Creative Commons Attribution License which permits any use, distribution, and reproduction in any medium, provided the original author(s) and the source are credited.

\section{References}

Flemish Advisory Council for Education. (2001). Samenwerking tussen school en ouders. [Cooperation between school and parents.]. Leuven: Garant.

Adams, K. S., \& Christenson, S. L. (2000). Trust and the family-school relationship: Examination of parentteacher differences in elementary and secondary grades. Journal of School Psychology, 38(5), 477-497.

Addi-Raccah, A., \& Ariv-Elyashiv, R. (2008). Parent empowerment and teacher professionalism: Teachers' perspective. Urban Education, 43(3), 394-415.

Anderson-Butcher, D. (2004). Transforming schools into 21 st century community learning centers. Children and Schools, 26(4), 248-252.

Bastiani, J. (1987). Parents and teachers; perspectives on home-school relations. London: Nfer-Nelson.

Cooper, H., Lindsay, J. J., \& Nye, B. (2000). Homework in the home: How student, family and parenting-style differences relate to the homework process. Contemporary Educational Psychology, 25, 464-487.

Crozier, G. (2000). Parents and schools; partners or protagonists? Stoke-on-Trent: Trentham Books.

Crozier, G. (2005). Activating participation; parents and teachers working towards partnerships. Stoke-onTrent: Trentham Books.

Crozier, G., \& Davies, J. (2007). Hard to reach parents or hard to reach schools? a discussion of home-school relations, with particular reference to Bangladeshi and Pakistani parents. British Educational Research Journal, 33(3), 295-313.

De Carvalho, M. E. P. (2001). Rethinking family-school relations: A critique of parental involvement in schooling. Mahwah: Lawrence Erlbaum.

De Vries, P. (2007). Handboek ouders in de school. [Handbook parents in the school.]. Apeldoorn: CPS.

De Wit, C. (2005). Ouders als educatieve partner. [Parents as an educational partner.]. Den Haag: Q*Primair.

Dearing, E., McCartney, K., Weiss, H. B., Kreider, H., \& Simpkins, S. (2004). The promotive effects of family educational involvement for low-income children's literacy. Journal of School Psychology, 42, 445-460.

Dearing, E., Kreider, H., Simpkins, S., \& Weiss, H. B. (2006). Family involvement in school and low-income children's literacy: Longitudinal associations between and within families. Journal of Educational Psychology, 98(4), 653-664. 
Desforges, C., \& Abouchaar, A. (2003). The impact of parental involvement, parental support and family education on pupil achievements and adjustment: A literature review. Research report 433. London: Department for Education and Skills.

Dom, L. (2006). Ouders en scholen. [Parents and schools.]. Gent: Academia.

Dutch Advisory Council for Education. (2003). Tel uit je zorgen. Onderwijszorgen van leerlingen, ouders, leraren en het bredere publiek. [Count your worries; Educational worries of pupils, parents, teachers and the public.]. Den Haag: Onderwijsraad.

Epstein, J. L. (2001). School, family and community partnerships; preparing educators and improving schools. Boulder: Westview.

Evangelou, M., Sylva, K., Edwards, A., \& Smith, T. (2008). Supporting parents in promoting early learning: The evaluation of the early learning partnership project. Nottingham: DCSF [DCSF-RR039].

Fan, X., \& Chen, M. (2001). Parental involvement and students' academic achievement: A meta-analysis. Educational Psychology Review, 13(1), 1-22.

Fantuzzo, J., MacWayne, C., \& Perry, M. A. (2004). Multiple dimensions of family involvement and their relations to behavioral and learning competencies for urban, low-income children. School Psychology Review, 33(4), 467-480.

Gonzalez-Dehass, A. R., Willems, P. P., \& Holbein, M. F. D. (2005). Examining the relationship between parental involvement and student motivation. Educational Psychology Review, 17(2), 99-123.

Hargrave, T. D., Jennings, G., \& Anderson, W. (2007). The development of a relational ethics scale. Journal of Marital and Family Therapy, 17(2), 145-158.

Harris, A., \& Chrispeels, J. H. (2006). Improving schools and educational systems; international perspectives. London: Routledge.

Harris, A., \& Goodall, J. (2007). Engaging parents in raising achievement; do parents know they matter? London: Department for Children, Schools and Families.

Harris, A., \& Goodall, J. (2008). Do parents know they matter? engaging all parents in learning. Educational Research, 50(3), 277-289.

Harris, A., Russ, J., Allen, T., \& Goodall, J. (2007). Reaching out; engaging hard to reach parents. Nottingham: Nottingham LA.

Hoff, E. (2006). How social contexts support and shape language development. Developmental Review, 26, 55-88.

Hooge, E. H. (2008). Op de grenzen van het onderwijs. Professioneel onderwijs in de grote stad. [On the borders of education; Professional urban education.]. Amsterdam: Amsterdam University Press.

Hooge, E. H., Honingh, M. E., \& Langelaan, B. N. (2011). The teaching profession against the background of educationalisation: An exploratory study. European Journal of Teacher Education, 24(4), 297-315.

Hoover-Dempsey, K. V., \& Sandler, H. M. (1995). Parental involvement in children's education: Why does it make a difference? Teachers College Record, 97, 310-331.

Hoover-Dempsey, K. V., \& Sandler, H. M. (1997). Why do parents become involved in their children's education? Review of Educational Research, 67, 3-42.

Hoover-Dempsey, K. V., Battiato, A. C., Walker, J. M. T., Reed, R. P., DeJong, J. M., \& Jones, K. P. (2001). Parental involvement in homework. Educational Psychologist, 36(3), 195-209.

Hoover-Dempsey, K. V., Walker, J. M. T., Jones, K. P., \& Reed, R. P. (2002). Teachers involving parents TIP: Results of an in-service teacher education program for enhancing parental involvement. Teaching and Teacher Education, 18, 843-867.

Hoover-Dempsey, K. V., Walker, J. M. T., Sandler, H. M., Whetsel, D., Green, C. L., Wilkins, A. S., \& Closson, K. (2005). Why do parents become involved? Research findings and implications. The Elementary School Journal, 106(2), 105-130.

Jeynes, W. (2003). A meta-analysis. The effects of parental involvement on minority children's academic achievement. Education and Urban Society, 35(2), 202-218.

Karsten, D., De Jong, U., Ledoux, G., \& Sligte, H. (2006). De positie van ouders en leerlingen in het governancebeleid. [The position of parents and pupils in governance policy.]. Amsterdam: SCOKohnstamminstituut, Universiteit van Amsterdam.

Kranenburg, D. (2009). Actief ouderschap en educatief partnerschap. [Active parenting and educational partnership.]. Praxisbulletin, 27(8), 5-9.

Lareau, A. (1997). Social class differences in family-school relationships: The importance of cultural capital. In A. H. Halsey, L. P. Brown, \& A. Wells (Eds.), Education, culture, economy, society. Oxford: Oxford University Press.

Leseman, P. M., \& De Jong, P. F. (1998). Home literacy: Opportunity, instruction, cooperation and socialemotional quality predicting early reading achievement. Reading Research Quarterly, 33(3), 294-318.

Leseman, P. P. M., Scheele, A. F., Mayo, A. Y., \& Messer, M. H. (2007). Home literacy as a special language environment to prepare children for school. Zeitschrift für Erziehungswissenschaft, 10(3), 334-349.

Lynch, J. (2009). Print literacy engagement of parents from low-income backgrounds: Implications for adult and family literacy programs. Journal of Adolescent \& Adult Literacy, 52(6), 509-521. 
McWayne, C., Hampton, V., Fantuzzo, J., Cohen, H. L., \& Sekino, Y. (2004). A multivariate examination of parent involvement and the social and academic competencies of urban kindergarten children. Psychology in the Schools, 41(3), 363-377.

Menheere, A., \& Hooge, E. H. (2010). Parental involvement in children's education: A review study about the effect of parental involvement on children's school education with a focus on the position of illiterate parents. Journal of the European Teacher Education Network (JETEN), 6, 144-157.

Merlo, L. J., Bowman, M., \& Barnet, D. (2007). Parental nurturance promotes reading acquisition in low socioeconomic status children. Early Education and Development, 18(1), 51-69.

Morrison Gutman, L., \& McLoyd, V. C. (2000). Parents' management of their children's education within the home, at school, and in the community: An examination of African-American families living in poverty. The Urban Review, 32(1), 1-23.

Oostdam, R. (2009). Tijd voor dikke leerkrachten; Over maatwerk als kern van goed onderwijs. [Time to fatten teachers; Tailor-made teaching as the essence of good education.]. Amsterdam: Amsterdam University Press.

Oostdam, R., \& Van Loo, T. (2011). Educatief partnerschap; Evalueren om te leren met ouders. [Educational partnership; assessment for learning with parents.]. In J. Castelijns, M. Segers, \& K. Struyven (Eds.), Evalueren om te leren; Toetsen en beoordelen op school. Bussum: Coutinho.

Patall, E. A., Cooper, H., \& Robinson, J. C. (2008). Parental involvement in homework: A research synthesis. Review of Educational Research, 78(4), 1039-1101.

Peetsma, T., \& Blok, H. (2007). Onderwijs op maat en ouderbetrokkenheid; Het integrale eindrapport. [Tailor-made education and parental involvement.]. Amsterdam: SCO-Kohnstamm Instituut.

Reay, D. (1998). Class work; mothers' involvement in their children's primary schooling. London: HMSO.

Sacker, A., Schoon, I., \& Bartley, M. (2002). Social inequality in educational achievement and psychological adjustment throughout childhood; magnitude and mechanisms. Social Science \& Medicine, 55, 863-880.

Smit, F., Sluiter, R., \& Driessen, G. (2006). Literatuurstudie ouderbetrokkenheid in internationaal perspectief. [Review study parental involvement in international perspective.]. Nijmegen: ITS, Radboud Universiteit Nijmegen.

Smit, F., Driessen, G., Sluiter, R., \& Brus, M. (2007). Ouders, scholen en diversiteit; Ouderbetrokkenheid en participatie op scholen met veel en weinig achterstandsleerlingen. [Parents, schools and diversity; Parental involvement in schools with many and few underprivileged pupils.]. Nijmegen: ITS, Radboud Universiteit Nijmegen.

Stevens, L. (1997). Overdenken en doen; Een pedagogische bijdrage aan adaptief onderwijs. [Reconsidering and act; A pedagogical contribution to adaptive education.]. 's-Gravenhage: Procesmanagement Primair Onderwijs.

Sylva, K., Melhuish, E. C., Sammons, P., Siraj-Blatchford, I., \& Taggert, B. (2004). The effective provision of Pre-school Education Project. Technical paper 12: Final report-effective pre-school education. London: University of London, Institute of Education.

Todd, E. S., \& Higgins, S. (1998). Powerless in professional and parent partnerships. British Journal of Sociology of Education, 19(2), 227-236.

Van Loo, J. (2004). Effectief communiceren met ouders. [Communicating effectively with parents.]. Alphen aan den Rijn: Kluwer.

Ron Oostdam. University of Amsterdam, Plantage Muidergracht 24, NL 1018 TV Amsterdam, the Netherlands. Phone: +31-20-5251330; E-mail: r.j.oostdam@uva.nl

Current themes of research:

Learning processes. Language education. Language testing. Measurement of intelligence. Test anxiety. Teacher training.

Most relevant publications in the field of Psychology of Education:

Gelderen, A. van, R. Oostdam, \& E. van Schooten (2011). Does foreign language writing benefit from increased lexical fluency?; evidence from a classroom experiment. Language Learning, 61(1), 281-321.

Oostdam, R., \& Meijer, J. (2011). Effects of instruction and stage-fright on intelligence testing. European Journal of Psychology of Education, 26, 143-161. 
Meijer, J., \& Oostdam, R. (2007). Test anxiety and intelligence testing: A closer examination of the stagefright hypothesis and the influence of stressful instruction. Anxiety, Stress and Coping, 20(1), 77-91.

Gelderen, A. van, \& Oostdam, R. (2004). Revision of form and meaning in learning to write comprehensible text. In L. Allal, L. Chanquoy \& P. Largy (Eds.), Revision: cognitive and instructional processes (pp. 103-123). Boston/Dordrecht/New York/London: Kluwer Academic Publishers.

Oostdam, R., \& Meijer, J. (2003). Influence of test anxiety on measurement of intelligence. Psychological Reports, 92, 3-20.

Edith Hooge. Amsterdam University of Applied Sciences, Wibautstraat 2-4, NL 1091 GM Amsterdam, the Netherlands. Phone: +31-6-245519 67; E-mail: e.h.hooge@hva.nl

Current themes of research:

Urban education. School leadership. Educational policy. Teacher training.

Most relevant publications in the field of Psychology of Education:

Hooge, E. H., M. E. Honingh \& Langelaan B. N. (2011). The teaching profession against the background of educationalisation: an exploratory study. European Journal of Teacher Education, 24(4), 297-315.

Menheere, A. \& Hooge, E.H. (2010). Parental involvement in children's education: A review study about the effect of parental involvement on children's school education with a focus on the position of illiterate parents. Journal of the European Teacher Education Network (JETEN), 6, 144-157.

Hooge, E. H. (2008). Op de grenzen van het onderwijs. Professioneel onderwijs in de grote stad. [On the borders of education; Professional urban education.] Amsterdam: Amsterdam University Press. 